\title{
Mass spectrometry-based investigation of measles and mumps virus proteome
}

\author{
Dora Sviben ${ }^{1,2^{*}}$ D, Dubravko Forcic ${ }^{1,2}$, Beata Halassy ${ }^{1,2}$, Günter Allmaier ${ }^{3}$, Martina Marchetti-Deschmann ${ }^{3}$ \\ and Marija Brgles ${ }^{1,2}$
}

\begin{abstract}
Background: Measles (MEV) and mumps virus (MUV) are enveloped, non-segmented, negative single stranded RNA viruses of the family Paramyxoviridae, and are the cause of measles and mumps, respectively, both preventable by vaccination. Aside from proteins coded by the viral genome, viruses are considered to contain host cell proteins (HCPs). The presence of extracellular vesicles (ECVs), which are often co-purified with viruses due to their similarity in size, density and composition, also contributes to HCPs detected in virus preparations, and this has often been neglected. The aim was to identify which virus-coded proteins are present in MEV and MUV virions, and to try to detect which HCPs, if any, are incorporated inside the virions or adsorbed on their outer surface, and which are more likely to be a contamination from co-purified ECVs.
\end{abstract}

Methods: MUV, MEV and ECVs were purified by ultracentrifugation, hydrophobic interaction chromatography and immunoaffinity chromatography, proteins in the samples were resolved by SDS-PAGE and subjected to identification by MALDI-TOF/TOF-MS. A comparative analysis of HCPs present in all samples was carried out.

Results: By proteomics approach, it was verified that almost all virus-coded proteins are present in MEV and MUV particles. Protein C in MEV which was until now considered to be non-structural viral protein, was found to be present inside the MeV virions. Results on the presence of HCPs in differently purified virus preparations imply that actin, annexins, cyclophilin $A$, moesin and integrin $\beta 1$ are part of the virions.

Conclusions: All HCPs detected in the viruses are present in ECVs as well, indicating their possible function in vesicle formation, or that most of them are only present in ECVs. Only five HCPs were constantly present in purified virus preparations, regardless of the purification method used, implying they are likely the integral part of the virions. The approach described here is helpful for further investigation of HCPs in other virus preparations.

Keywords: Measles virus, Mumps virus, Extracellular vesicles, Host cell proteins, Mass spectrometry

\section{Background}

Measles (MEV) and mumps (MUV) viruses are non-segmented, negative single stranded RNA viruses from the family Paramyxoviridae which cause measles and mumps, respectively. MEV and MUV virions are enveloped with lipid membrane derived from the host cell plasma membrane and are pleomorphic in shape, with diameter in range 100-900 $\mathrm{nm}[1-5]$.

\footnotetext{
* Correspondence: dora.sviben@gmail.com

${ }^{1}$ Centre for Research and Knowledge Transfer in Biotechnology, University of Zagreb, Rockefellerova 10, HR-10 000 Zagreb, Croatia

${ }^{2}$ Centre of Excellence for Viral Immunology and Vaccines, CERVirVac, Zagreb, Croatia

Full list of author information is available at the end of the article
}

Genomic RNAs of MEV and MUV have 15,894 and 15,384 base pairs coding in total for 8 and 9 viral proteins, respectively. Viral RNA is packed into a filamentous complex called nucleocapsid by the nucleoprotein (denoted NP for MUV and N for MEV) which interacts with large polymerase $(\mathrm{L})$ through phosphoprotein $(\mathrm{P})$. This core unit, also referred to as ribonucleocapsid, is linked to the matrix protein (M) found directly below virion's lipid bilayer [6-9].

Lipid bilayer is spiked with two types of glycoproteins: attachment proteins, hemagglutinin - neuraminidase $(\mathrm{HN})$ in MUV and hemagglutinin $(\mathrm{H})$ in MEV, are responsible for virus attachment to the surface of the host cell, and fusion protein (F) is responsible for the fusion

(c) The Author(s). 2018 Open Access This article is distributed under the terms of the Creative Commons Attribution 4.0 International License (http://creativecommons.org/licenses/by/4.0/), which permits unrestricted use, distribution, and 
of virus and cell membrane in both viruses [10]. F protein of MEV and MUV is synthesized as an inactive precursor $F_{0}$. Its active form consists of two fragments $F_{1}$ and $F_{2}$ linked with disulphide bridges formed after cleavage by host cell protease furin which specifically recognizes the RRHKR motif $[2,3]$.

In both MEV and MUV, the transcription of the $\mathrm{P}$ gene results in three mRNA transcripts coding for P/V/I proteins in MUV and $\mathrm{P} / \mathrm{V} / \mathrm{C}$ proteins in $\mathrm{MEV}[11,12]$. $\mathrm{V} / \mathrm{I}$ and $\mathrm{V} / \mathrm{C}$ are often considered as non-structural proteins, and it was reported that they are not necessary for virus replication in Vero cells [13-16].

MUV genome codes for another, small hydrophobic protein $(\mathrm{SH})$. This non-structural protein also seems not to be necessary for MUV replication [17], and is considered to be a membrane protein present in the lipid bilayer [18].

MEV and MUV genomes are explored in detail, but the studies of their proteomes were mostly carried out during 1970s and 1980s, prior to development of high sensitivity "soft ionization" mass spectrometric methods [19-31]. In these early studies, up to 6 viral proteins were usually detected $-\mathrm{H} / \mathrm{HN}, \mathrm{P}, \mathrm{N} / \mathrm{NP}, \mathrm{M}$ and F were readily confirmed in virus samples, and some groups also detected the $\mathrm{L}$ protein in their preparations [22, 26, 29-31]. These early investigations relied on gel electrophoresis for determination of molecular masses of proteins, combined with labelling newly synthesized proteins by radioactive amino acids $\left({ }^{14} \mathrm{C}\right.$-labeled amino acid mixtures, ${ }^{3} \mathrm{H}$-leucine or ${ }^{35} \mathrm{~S}$-methionine), and detection of glycoproteins by incorporation of ${ }^{3} \mathrm{H}$-glucosamine. Recently, MUV proteome was investigated by mass spectrometry for the first time and the presence of 6 virus polypeptides was confirmed: L, HN, NP, P, M and V [32].

Apart from virus-coded proteins, it is considered that various enveloped viruses incorporate also host cell proteins (HCPs), inside the viral particle and in the lipid bilayer [33]. Presence of HCPs in virus preparations is important both for basic research of the biology of these viruses, as well as for the vaccine production in industry because it means that the vaccine is not only carrying viral, but also HCP antigens [34]. Early investigations of MEV and MUV already reported the presence of cellular actin in virions $[21,26,28]$, and additional HCPs such as fibronectin, clathrin and histones were detected in MUV samples investigated recently [32]. There are indications that some HCPs are specifically taken up by the viral particles, by direct interactions with viral proteins [34-36], but HCPs might also be incorporated non-specifically [37], can be adsorbed to the outer surface of the virion, or be present as contamination arising from the presence of cellular debris or extracellular vesicles (ECVs) in virus preparations $[38,39]$. ECVs are produced by virtually all types of cells [40], and their similarity to viruses in size, density, and composition (e.g. proteins, lipids, nucleic acids), as well as the lack of clear line between ECVs and different types of non-infectious virus particles [41], makes their detection and thus separation from viruses extremely difficult. Some attempts to obtain ECV-free virus preparations have been made by treating the samples with proteases or by CD45 immunoaffinity depletion followed by density gradient ultracentrifugation [34, 37]. However, the presence of ECVs is still often disregarded in papers discussing virus proteomes, or they are mentioned as minor contaminants [42] which might not always be the case. There are results that imply that, if production of ECVs in non-infected and infected cells is the same, about one third of particles in virus suspensions are ECVs [43]. The main reasons for disregarding the presence of ECVs are probably problems with detecting and separating ECVs from viruses, combined with lack of awareness that both types of particles are secreted simultaneously. However, this raises questions about the conclusions drawn from such reports regarding HCPs present inside the virions.

\section{Methods}

The aim of this research was to identify which virus coded proteins are present in MEV and MUV, and to detect which HCPs, if any, are attached to or potentially incorporated inside the virions. Since presence of ECVs in virus samples complicates this assessment, for the first time the evaluation of which HCPs might be part of the virions was carried out by comparison of HCPs detected in virus preparations purified by different purification methods (immunoaffinity chromatography, IAC, hydrophobic interaction chromatography, HIC, and ultracentrifugation, UC), and with HCPs present in ECVs produced by non-infected Vero cells. An attempt to evaluate which HCPs might be part of the virions, and which are more likely to be contaminants, was made under the hypothesis that HCPs present in all viral samples, regardless of the purification method used, are more likely to be incorporated in or attached to virions, whereas others are probably contaminants arising from ECVs co-purified with viruses. To support the hypothesis that HCPs which are detected only in some virus preparations are arising from the ECVs, the proteomes of ECVs purified from the supernatants of the non-infected Vero cells were also analysed and compared to proteomes of MEV and MUV.

\section{Cell cultures}

Vero cell culture (African green monkey kidney cells) was obtained from European Collection of Animal Cell Culture (ECACC) and maintained in minimum essential medium with Hank's salts (MEM-H) (AppliChem) supplemented with $10 \%(v / v)$ FCS (Invitrogen) and $50 \mu$ g neomycin $\mathrm{mL}^{-1}$ (Gibco-Life Technologies). 


\section{Virus production and purification}

MEV strain Edmonston-Zagreb and MUV strain L-Zagreb were obtained from Institute of Immunology, Zagreb, Croatia. Vero cells were infected with MEV or MUV in suspension at m.o.i. of 0.005 or 0.001 , respectively, in MEM-H with $2 \%(\mathrm{v} / \mathrm{v})$ FCS. The medium was replaced with medium without FCS after $24 \mathrm{~h}$, and virus was further grown until cytopathic effect was observed.

The culture supernatant was collected and clarified by microfiltration through $0.45 \mu \mathrm{m}$ PVDF syringe filter (Millipore). Viruses were then subjected to purification by UC, HIC or IAC as previously described [5, 43, 44]. Briefly, viruses were purified by HIC on CIM OH monolithic column (column volume, CV $1 \mathrm{~mL}$, channel size $6 \mu \mathrm{m}$ ) (BIA Separations) with binding buffer $50 \mathrm{mM}$ HEPES, $1.0 \mathrm{M}\left(\mathrm{NH}_{4}\right)_{2} \mathrm{SO}_{4}$, pH 7.3 and eluted by step gradient elution with $0.5 \mathrm{M}$ and $0 \mathrm{M}\left(\mathrm{NH}_{4}\right)_{2} \mathrm{SO}_{4}$ in $50 \mathrm{mM}$ HEPES. In IAC, MUV suspension was loaded on CIM epoxy monolithic column coupled with polyclonal anti-MUV antibodies (CV $1 \mathrm{~mL}$, channel size $6 \mu \mathrm{m}$ ) (BIA Separations) with binding buffer $20 \mathrm{mM}$ MOPS, $0.15 \mathrm{M}$ $\mathrm{NaCl}, \mathrm{pH} 7.3$ and eluted with solutions containing $0.75 \mathrm{M}$ Arg/ 0.75 M imidazole or $0.75 \mathrm{M} \mathrm{Arg/0.75} \mathrm{M} \mathrm{Ser,} \mathrm{all} \mathrm{at}$ $\mathrm{pH}$ 7.3. Obtained eluates were additionally concentrated by UC for $2 \mathrm{~h}$ at $141,000 \times g$ to remove free or loosely bound proteins from the surface of the particles, which might co-purify during chromatography. For UC purification, only one-step UC for $2 \mathrm{~h}$ at $141,000 \times g$ was used and the obtained pellets were resuspended in $250 \mu \mathrm{L}$ PBS.

Supernatants obtained from non-infected Vero cell culture containing only ECVs were purified in the same way as described for virus suspensions.

\section{Virus quantification}

Quantification of viable virus particles was performed using a $\mathrm{CCID}_{50}$ assay as described elsewhere $[45,46]$. Total particle concentration and particle size in virus and ECV samples was determined by Nanoparticle Tracking Analysis (NTA), using a Nanosight LM10 instrument (Malvern) which consists of a conventional optical microscope, sCMOS camera and a LM10 unit with a red laser light source. High particle concentration samples were diluted with PBS prior to measurements to achieve concentration range $2-8 \times 10^{8}$ particles $/ \mathrm{mL}$. For each sample three $60 \mathrm{~s}$ videos of particles under Brownian motion were obtained with camera level fixed at 10 and analysed with detection threshold 5 using NTA 3.2 software.

\section{Protein analysis}

Virus samples were subjected to SDS gel electrophoresis under denaturing and reducing conditions in 1× NuPAGE LDS Sample Buffer (Invitrogen) with 10\% NuPAGE Reducing Agent (Invitrogen). NuPAGE 4-12\% Bis-Tris precast gels (Invitrogen) were used with MES running buffers and
Novex Sharp Pre-stained Protein Standard (Invitrogen) in an XCell Sure Lock system (Invitrogen) according to manufacturer's instructions. Protein band detection was performed by using acidic Coomassie Brilliant Blue R250 solution or by silver staining as described previously [47].

Protein bands were excised from the gel, digested by trypsin (porcine, Roche), peptides were extracted from the gel, purified and prepared for MS analysis as described previously [48].

\section{MALDI MS analysis}

Measurements were performed on UltrafleXtreme (Bruker) mass spectrometer in positive, reflectron ion mode. The instrument is equipped with $2 \mathrm{kHz}$ SmartBeam solid state laser $(355 \mathrm{~nm})$, and the applied acceleration voltage was $8 \mathrm{kV}$ in the positive mode. MS/MS spectra were obtained in the LIFT mode with the isolation of the monoisotopic peak. Obtained spectra were processed using FlexAnalysis (3.4.76.0) and BioTools (3.2. SR3) and identification searches were performed against NCBIprot database "Other viruses" and "Primates" (release 217, 12/2016 and release 221, 08/2017 with 198,565,475 and 203,180,606 sequences, respectively), and against contaminants database. Following parameters were used during searches: precursor ion mass tolerance $\pm 200 \mathrm{ppm}$, product ion mass $\pm 1.0 \mathrm{Da}$, two missed trypsin cleavages, constant carbamidomethylation of Cys and variable modifications: $\mathrm{N}$-acetylation, $\mathrm{C}$-amidation, ammonia loss from N-terminal Cys, modification of N-terminal Gln to pyro-Glu, oxidation of Met, His or Trp, phosphorylation of Ser, Thr or Tyr. Proteins were identified by peptide mass fingerprint (PMF) and peptide sequencing, with a minimum of 4 sequenced peptides identifying the protein.

\section{Results}

The genomes of MEV and MUV are well explored, but the proteome of MUV was only recently investigated by mass spectrometry (MS) [32], which is currently the dominant method in the field [49]. This is the first investigation of MEV proteome by MS, to the best of author's knowledge. MEV and MUV genomes encode for 8 and 9 proteins (Additional file 1, Tables $\mathrm{S} 1$ and $\mathrm{S} 2$, respectively), but it is important to investigate if all or just a subset of them are synthesized and present in the viral particle. It is also essential to try to identify which HCPs are a part of the virions, and which are present just as contaminations in virus preparations. It should be mentioned here that some of the viral proteins may also be included into ECVs inevitably present in the virus preparations [41].

MEV and MUV proteomes of viruses purified by UC and $\mathrm{HIC}$, and for MUV also by IAC, were analysed and compared. A comparison of the proteomes of viruses purified by different purification methods, as well as the comparison with proteomes of ECVs purified from non-infected cell culture supernatants by the same methods, was carried out 
to try and determinate which HCPs are virion-associated. All viral samples contained infective particles (determined by $\mathrm{CCID}_{50}$ assay), and data regarding total and infective particles of all analysed samples is given in Table 1.

\section{Samples purified by ultracentrifugation \\ MEV}

MALDI-TOF/TOF-MS analysis of MEV purified by UC in three separately prepared samples (Fig. 1) confirmed the presence of 7 out of 8 viral proteins: L, H, P, N, F, M and C. Protein $\mathrm{C}$ was detected for the first time in all three samples, at the apparent molecular mass (MM) which corresponds well to its theoretical molecular mass calculated from the amino acid sequence $\left(\mathrm{MM}_{\mathrm{aa}}\right)$ of $21 \mathrm{kDa}$.

Protein $\mathrm{H}$ was found in 5 to 7 bands, at MMs of $70 \mathrm{kDa}$ and higher, which is higher than its $\mathrm{MM}_{\mathrm{aa}}(69 \mathrm{kDa})$.

Protein $\mathrm{N}$ was found in 3 to 5 different bands at MMs equal or lower than $\mathrm{MM}_{\mathrm{aa}}(59 \mathrm{kDa})$, indicating the presence of truncated forms. Analysis of peptide mass fingerprint (PMF) and MS/MS spectra revealed that, for the $56 \mathrm{kDa}$ band, peptides from positions 33-521 were sequenced, indicating that this protein is not C-terminally truncated (Additional file 1: Figure S1), but could be $\mathrm{N}$-terminally truncated. However, comparison of peptides detected in the PMF spectra of the rest of the bands does not provide further evidence to support or rebut this hypothesis, hence further investigation is needed.

Protein F appears in multiple bands at MMs equal and higher than its $\mathrm{MM}_{\mathrm{aa}}$ (Fig. 1(a) and (c)). Peptides corresponding to fragment $F_{1}$ were found in all bands, however successfully sequenced peptides did not give any further insights on protein forms present in different bands (Additional file 1: Figure S2). Multiple bands containing $F_{1}$ are present in the $50-55 \mathrm{kDa}$ range, however their origin is unclear for now.
$\mathrm{M}$ protein also appears in multiple bands, at MMs equal and higher than $\mathrm{MM}_{\mathrm{aa}}(37 \mathrm{kDa})$. Here, several bands are consistently present in the $40-60 \mathrm{kDa}$ range.

$\mathrm{P}$ protein is found in 2 to 3 bands, at approximately $53 \mathrm{kDa}$ corresponding well to $\mathrm{MM}_{\mathrm{aa}}$ of $\mathrm{P}(54 \mathrm{kDa})$, at approximately $60 \mathrm{kDa}$, and in bands at higher $\mathrm{MMs}$ (110 kDa and more).

\section{MUV}

MUV purified by UC (Fig. 2) contained numerous bands. Here, 6 viral proteins were detected: $\mathrm{L}, \mathrm{HN}, \mathrm{NP}, \mathrm{M}, \mathrm{V}$ and $\mathrm{F}_{2}$.

Protein $\mathrm{HN}$ was detected at MMs ranging from 70 to $200 \mathrm{kDa}$, in 2 to 4 bands, which are higher than its $\mathrm{MM}_{\mathrm{aa}}$ $(64 \mathrm{kDa})$.

Protein NP was detected in 3 to 4 bands at MMs equal or lower than $\mathrm{MM}_{\mathrm{aa}}$, ranging from approximately 39 to $61 \mathrm{kDa}$. Comparison of detected peptides in the PMF spectra (Additional file 1: Figure S3) might indicate C-truncation of proteins present in the bands at MMs lower than $61 \mathrm{kDa}$.

$F_{0}$ precursor and $F_{1}$ fragment remained undetected in UC purified MUV, but $F_{2}$ fragment was for the first time successfully detected in the sample in Fig. 2(c) at MM slightly higher than its $\mathrm{MM}_{\mathrm{aa}}(11 \mathrm{kDa})$. Proteins $\mathrm{L}$ and V was also detected in MUV, in the area corresponding to their $\mathrm{MM}_{\mathrm{aa}}$.

\section{Samples purified by hydrophobic interaction chromatography MEV}

Analysis of MEV purified by HIC (Fig. 3) confirmed the presence of 5 out of 8 viral proteins: $\mathrm{H}, \mathrm{P}, \mathrm{N}, \mathrm{F}$ and $\mathrm{M}$. Viral protein $\mathrm{H}$ was detected in 3 and 4 bands in eluates $\mathrm{E} 1$ and E2, respectively, at MMs ranging from 70 to $170 \mathrm{kDa}$, which are higher than its $\mathrm{MM}_{\mathrm{aa}}(69 \mathrm{kDa})$.

Protein $\mathrm{N}$ was detected in 2 bands - at approximately $59 \mathrm{kDa}$, corresponding well to $\mathrm{MM}_{\mathrm{aa}}$ of $\mathrm{N}$, and at $55 \mathrm{kDa}$.

Table 1 Total and infective particle concentrations in the analysed samples

\begin{tabular}{|c|c|c|c|c|c|c|c|c|c|c|c|}
\hline & \multicolumn{3}{|c|}{ UC } & \multicolumn{5}{|c|}{$\mathrm{HIC}^{\mathrm{ab}}$} & \multicolumn{3}{|c|}{$I A C^{a}$} \\
\hline & \multirow[b]{2}{*}{$n$} & \multirow[b]{2}{*}{$\begin{array}{l}\text { Total } \\
\text { particles/ } \\
\log _{10} \text { units } \\
\mathrm{mL}^{-1}\end{array}$} & \multirow[b]{2}{*}{$\begin{array}{l}\text { Infective } \\
\text { particles/ } \\
\text { lo }_{10} \mathrm{CCID}_{50} \\
\text { units } \mathrm{mL}^{-1}\end{array}$} & \multicolumn{3}{|c|}{ E1 } & \multicolumn{2}{|l|}{ E2 } & \multirow[b]{2}{*}{$n$} & \multirow[b]{2}{*}{$\begin{array}{l}\text { Total particles/ } \\
\log _{10} \text { units } \mathrm{mL}^{-1}\end{array}$} & \multirow[b]{2}{*}{$\begin{array}{l}\text { Infective particles/ } \\
\log _{10} \mathrm{CCID}_{50} \\
\text { units } \mathrm{mL}^{-1}\end{array}$} \\
\hline & & & & $n$ & $\begin{array}{l}\text { Total } \\
\text { particles/ } \\
\log _{10} \text { units } \\
\mathrm{mL}^{-1}\end{array}$ & $\begin{array}{l}\text { Infective particles/ } \\
\log _{10} \mathrm{CCID}_{50} \\
\text { units } \mathrm{mL}^{-1}\end{array}$ & $\begin{array}{l}\text { Total particles/ } \\
\log _{10} \text { units } \mathrm{mL}^{-1}\end{array}$ & $\begin{array}{l}\text { Infective particles/ } \\
\log _{10} \mathrm{CCID}_{50} \\
\text { units } \mathrm{mL}^{-1}\end{array}$ & & & \\
\hline MEV & 3 & $\begin{array}{l}\text { (A) } 11.934 \\
\text { (B) } 11.387 \\
\text { (C) } 11.873\end{array}$ & $\begin{array}{l}9.135 \\
9.765 \\
7.705\end{array}$ & 3 & 8.619 & 5.614 & 9.113 & 6.333 & 0 & NA & NA \\
\hline MUV & 3 & $\begin{array}{l}\text { (A) ND } \\
\text { (B) } 12.002 \\
\text { (C) } 12.310\end{array}$ & $\begin{array}{l}6.422 \\
7.946 \\
7.085\end{array}$ & 3 & 9.026 & 7.835 & 9.462 & 8.174 & 2 & $\begin{array}{l}\text { (A) ND } \\
\text { (B) } 9.200\end{array}$ & $\begin{array}{l}\text { (A) ND } \\
\text { (B) } 6.832\end{array}$ \\
\hline ECV & 2 & $\begin{array}{l}\text { (B) } 11.700 \\
\text { (C) } 11.939\end{array}$ & $\begin{array}{l}\text { NA } \\
\text { NA }\end{array}$ & 1 & 8.379 & NA & 8.874 & NA & 1 & 8.798 & NA \\
\hline
\end{tabular}

\section{ND not deterined}

$n$ - number of samples analysed; (A), (B), (C) - data corresponding to separately prepared samples denoted in the same way in corresponding figures

a - pooled sample from 4 subsequent days;

b - calculated average value for the pool after concentration by UC (\% recovery calculated based on UC data presented in [5]); only data for the representative sample in Figs. 3 and 4 are given here 


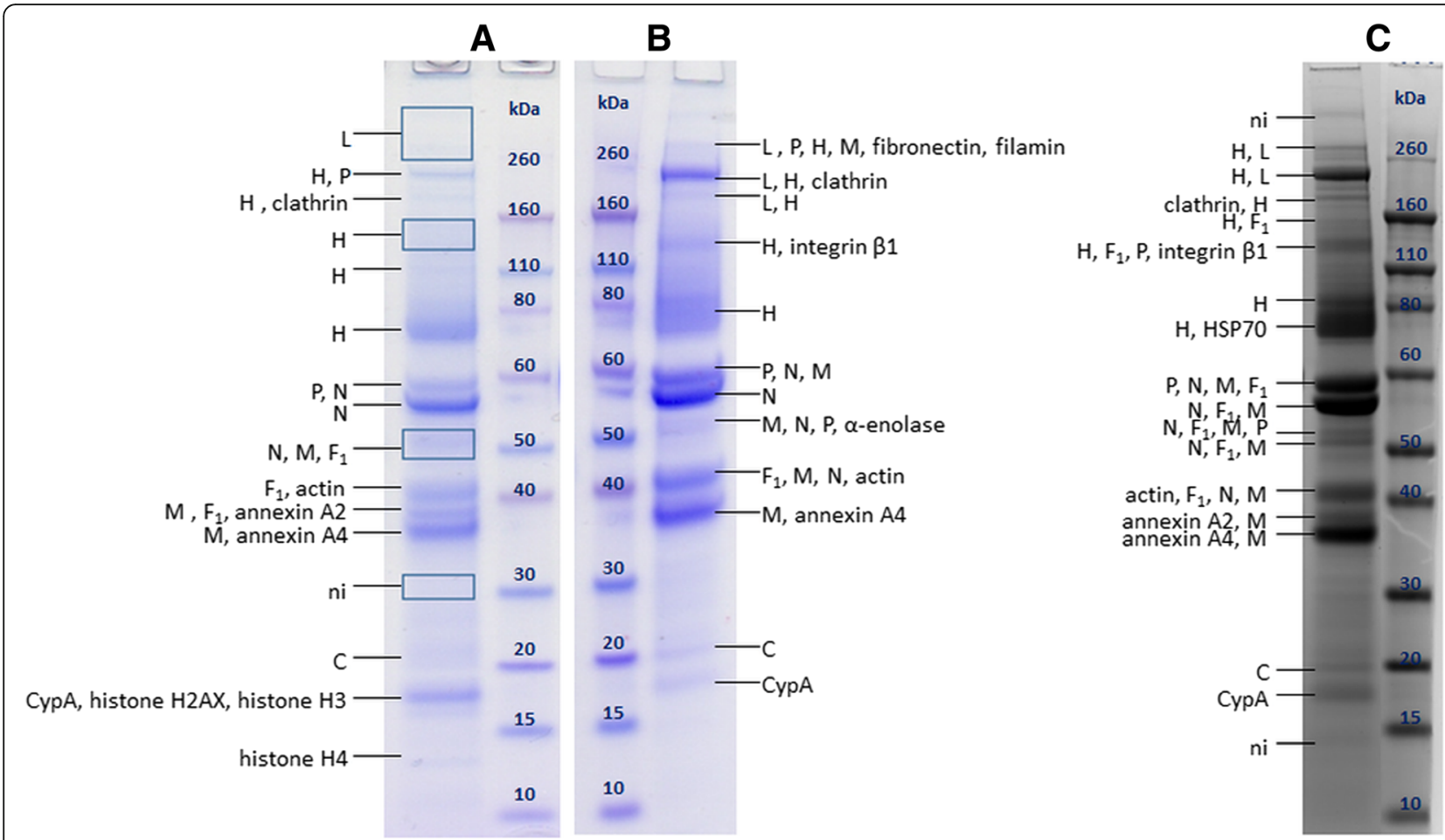

Fig. 1 SDS-PAGE of MEV sample purified by UC with protein annotations after MALDI-TOF/TOF MS analysis. $\mathbf{a}$, $\mathbf{b}$ and $\mathbf{c}$ represent three separately prepared samples for which the data are listed in Table 1. CypA - cyclophilin A, HSP - heat shock protein, ni - not identified. Rectangles denote areas where large gel pieces (possibly containing multiple but very faint bands) were excised

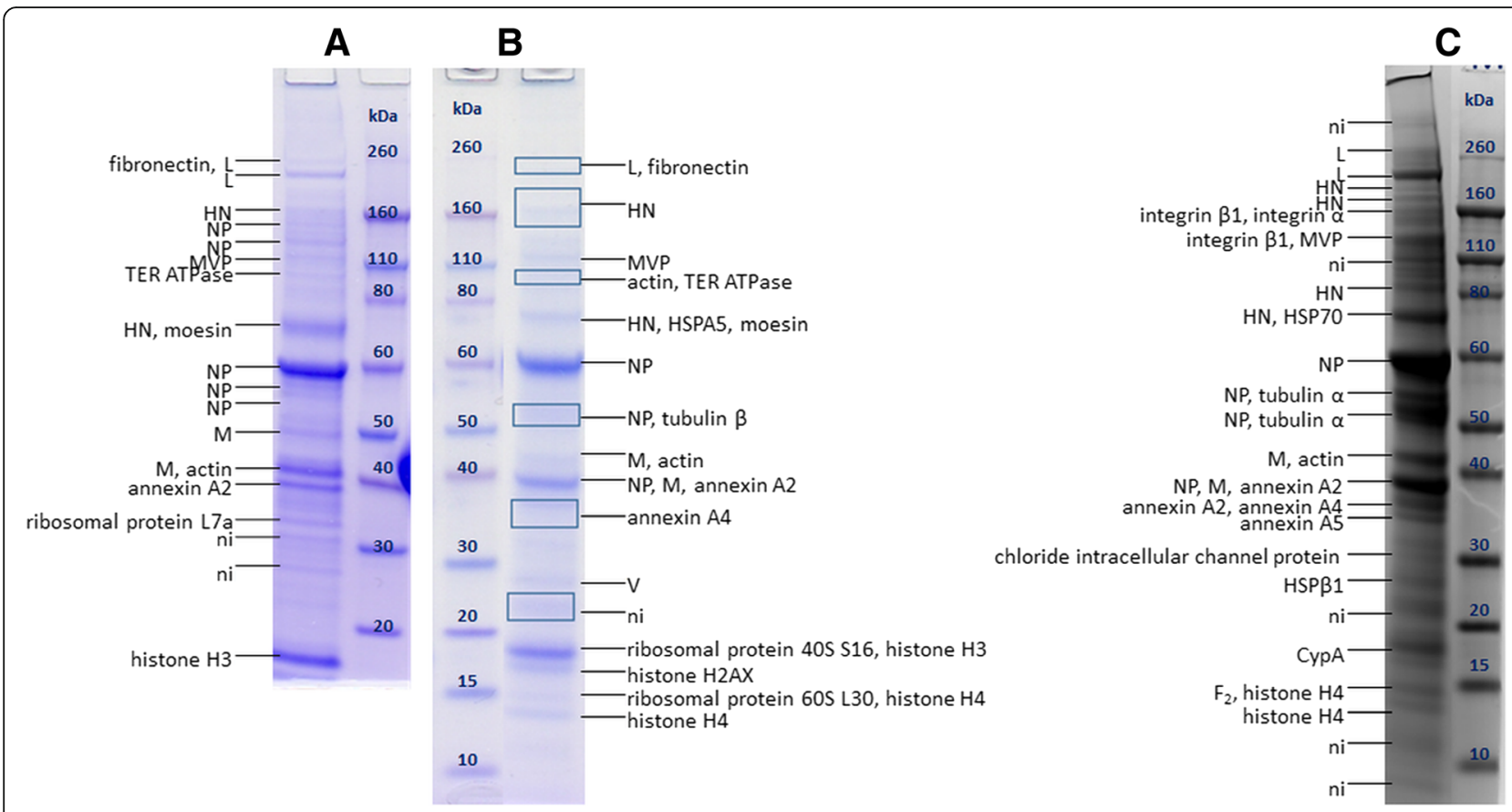

Fig. 2 SDS-PAGE of MUV sample purified by UC with protein annotations after MALDI-TOF/TOF MS analysis. $\mathbf{a}$, $\mathbf{b}$ and $\mathbf{c}$ represent three separately prepared samples for which the data are listed in Table 1. MVP - major vault protein, TER ATPase - transitional endoplasmatic reticulum ATPase, HSP - heat shock protein, CypA - cyclophilin A, ni - not identified. Rectangles denote areas where large gel pieces (possibly containing multiple but very faint bands) were excised 
Peptides corresponding to $\mathrm{F}_{1}$ fragment were again detected at MMs comparable to its $\mathrm{MM}_{\mathrm{aa}}(47 \mathrm{kDa})$, whereas no protein bands were observed in the range where $F_{2}$ should be present.

\section{MUV}

Analysis of MUV purified by HIC (Fig. 4) revealed for the first time the presence of more than 6 viral proteins in one sample. Here, 7 out of 9 viral proteins were successfully detected: L, HN, NP, P, M, F and V.

Protein $\mathrm{HN}\left(\mathrm{MM}_{\mathrm{aa}} 64 \mathrm{kDa}\right)$ was detected in two bands at approximately 70 and $150 \mathrm{kDa}$.

Protein NP $\left(\mathrm{MM}_{\mathrm{aa}} 61 \mathrm{kDa}\right)$ was detected in two bands (approximately 46 and $56 \mathrm{kDa}$ ). Comparison of peptides present in the PMF spectra (Additional file 1: Figure S5) of these two bands indicates that both bands contain C-terminally truncated forms of NP. Peptides corresponding to the sequence positions $461-513$ of $56 \mathrm{kDa}$ protein were not sequenced, but only observed in the PMF spectra, however MM of protein truncated at position 513 would be $57 \mathrm{kDa}$ which corresponds well to $\mathrm{MM}$ of the protein calculated from the position on the gel. When the same analysis was performed for protein truncated at position 400 , the calculated MM again corresponds to the protein MM estimated from the gel (46 kDa). This hypothesis should however be further corroborated. Full-length NP appears not to be detected in this sample.

Protein $\mathrm{F}$ was detected in two bands around $57 \mathrm{kDa}$ (only peptides of $F_{1}$ fragment) and around $65 \mathrm{kDa}$ (peptides from both $F_{1}$ and $F_{2}$ fragments).

\section{MUV purified by immunoaffinity chromatography}

In MUV purified by IAC, 6 out of 9 viral proteins were detected: L, HN, F, M, NP and V (Fig. 5). For the first time all three forms of $F$ protein in one sample were detected $-F_{0}$, $F_{1}$ and $F_{2} . F_{2}$ appears in 3 bands with quite different MMs, the lowest corresponding well to $\mathrm{MM}_{\mathrm{aa}}(11 \mathrm{kDa})$.

Proteins HN and NP appear in multiple bands, with the same patterns observed in samples purified by UC and HIC. P protein was surprisingly again not detected. In the sample shown in Fig. 5(a), protein $M$ is also present in multiple bands at higher MMs than its $\mathrm{MM}_{\mathrm{aa}}$, similar as observed for MEV $\mathrm{M}$ in the UC purified sample. The underlying cause remains unknown.

\section{Comparison of protein composition of viruses and ECVs purified by different purification methods}

Figure 6 shows ECVs purified by HIC (Fig. 6(a)), UC (Fig. 6(b) and (c)) and IAC (Fig. 6(d)). A concise list of HCPs found in all analysed MUV, MEV and ECV samples is given in Table 2. Some HCPs were detected in MUV and MEV only when UC purified samples were additionally analysed by 2D gel electrophoresis (Additional file 1: Figure S6 and Table S3).

Actin, annexins, cyclophilin A (CypA), integrin $\beta 1$ and moesin were consistently found in both virus and ECV samples, regardless of the purification method. Fibronectin was found in MUV and MEV, as well as ECVs, and in fraction E1 of HIC purified samples it was present in very high concentrations.

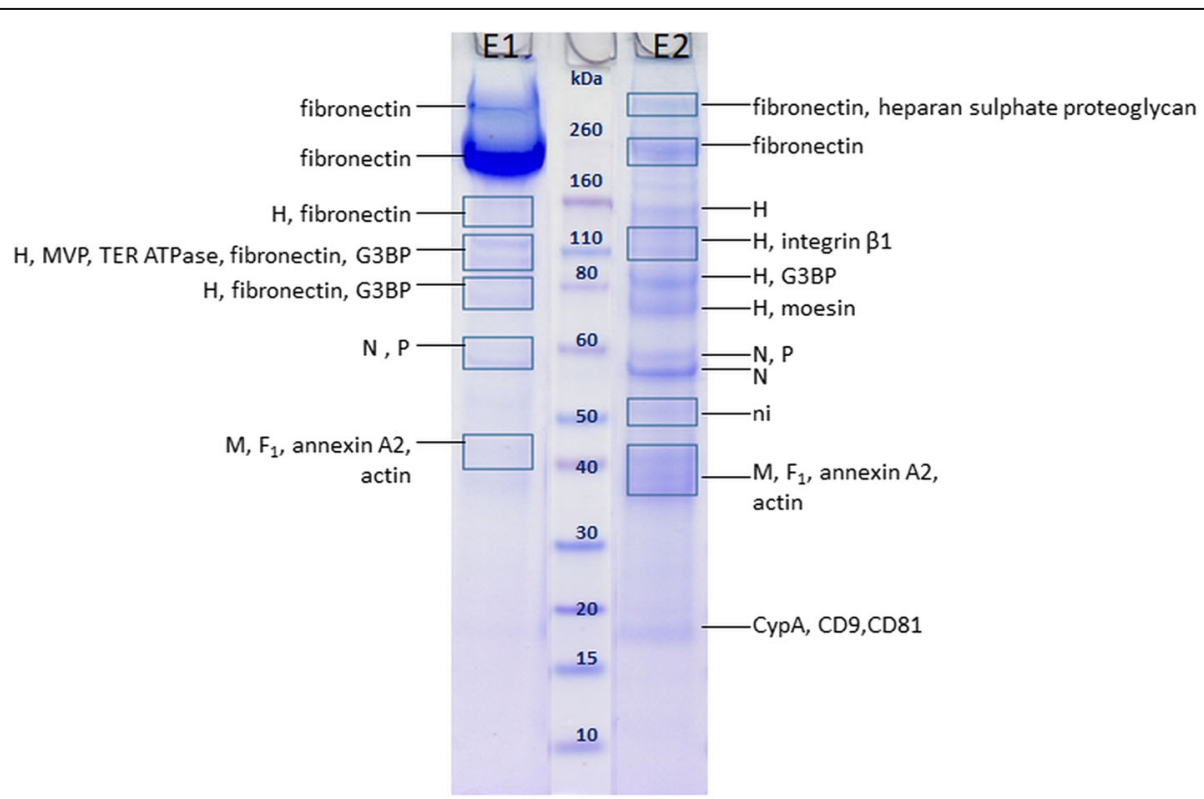

Fig. 3 SDS-PAGE of a representative MEV sample purified by HIC with protein annotations after MALDI-TOF/TOF MS analysis. Three separate

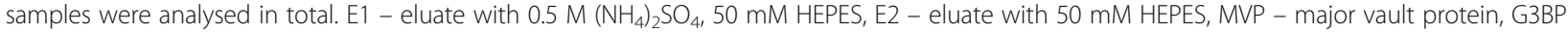
- galectin-3-binding protein, CypA - cyclophilin A, TER ATPase - transitional endoplasmatic reticulum ATPase, ni - not identified. Rectangles denote areas where large gel pieces (possibly containing multiple but very faint bands) were excised 


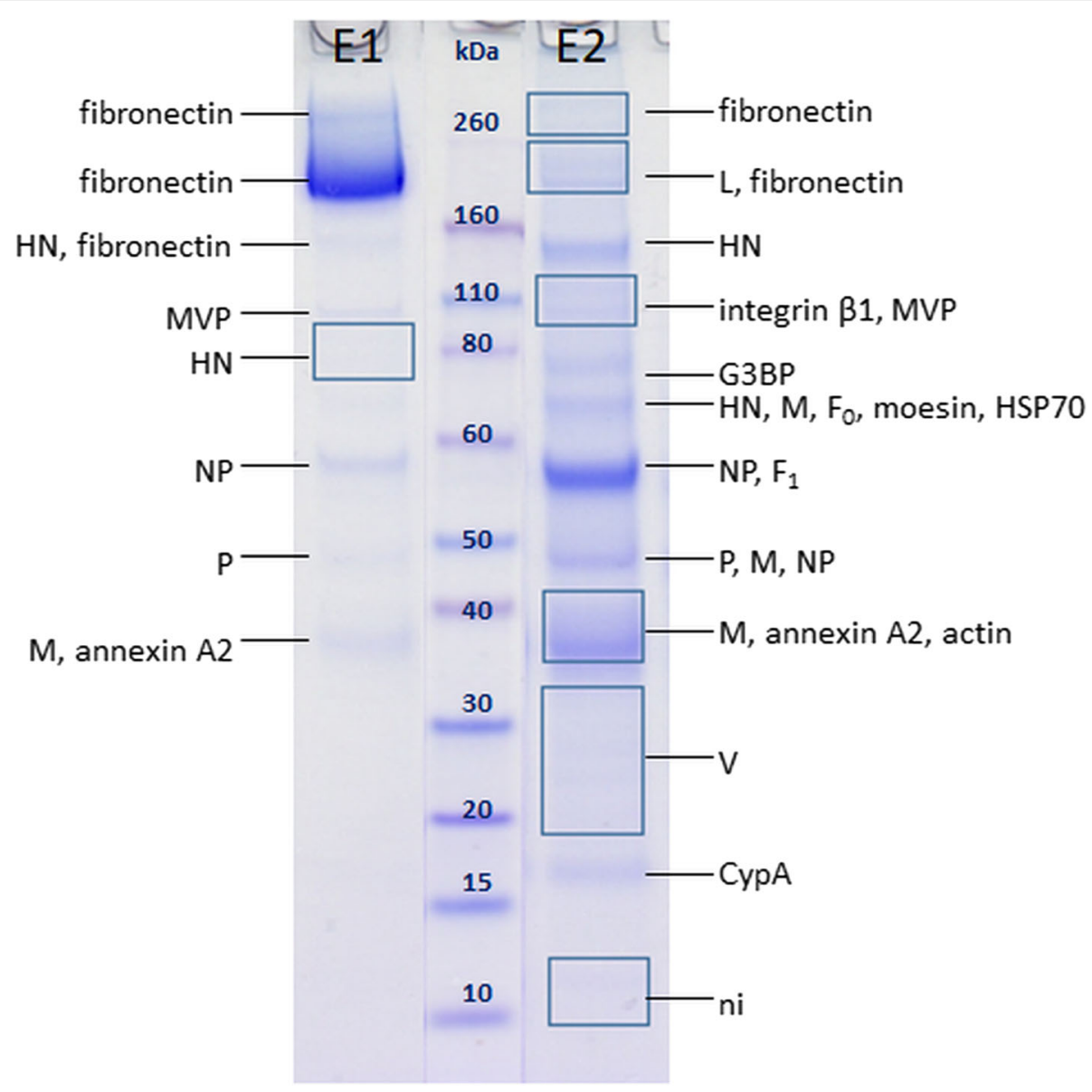

Fig. 4 SDS-PAGE of a representative MUV sample purified by HIC with protein annotations after MALDI-TOF/TOF MS analysis. Three separate samples were analysed in total. E1 - eluate with $0.5 \mathrm{M}\left(\mathrm{NH}_{4}\right)_{2} \mathrm{SO}_{4}, 50 \mathrm{mM}$ HEPES, E2 - eluate with $50 \mathrm{mM}$ HEPES, MVP - major vault protein, G3BP - galectin-3-binding protein, CypA - cyclophilin A, ni - not identified. Rectangles denote areas where large gel pieces (possibly containing multiple but very faint bands) were excised

\section{Discussion}

\section{MEV}

Protein $\mathrm{C}$ was detected in UC purified MEV. Until now it was only reported to be synthesized in Vero cells, but this was the first time it was found in MEV virions [29]. The intensities of the bands containing protein $\mathrm{C}$ indicate its low abundance in virus samples, which might explain why $\mathrm{C}$ was not detected in HIC purified MEV samples. V and $\mathrm{C}$ were until now considered non-structural MEV proteins, and were found not to be necessary for replication of MEV in Vero cells $[2,13,14]$. Therefore, it is very interesting that $\mathrm{C}$ is in fact packed into MEV virions. Protein $\mathrm{V}$ was not detected in MEV samples, possibly due to even lower abundance than $\mathrm{C}$, or absence from the virions.

Detection of protein $\mathrm{H}$ in up to 7 bands in MEV samples implies the presence of various glycoforms as well as the presence of both monomer and dimer on the gel, as previously described [27].

Occurrence of protein $\mathrm{N}$ in multiple bands at $\mathrm{MM}$ equal and lower than $\mathrm{MM}_{\mathrm{aa}}$ is in agreement with previous results which hypothesized that minor bands ranging from 40 to $55 \mathrm{kDa}$ belong to breakdown products of $\mathrm{N}$ protein or its truncated forms $[23,32]$. It is also interesting to notice that the intensity of the $55-56 \mathrm{kDa}$ band in the samples is typically higher than of that at $59 \mathrm{kDa}$. This might be the result of changes in transcription or translation, or $59 \mathrm{kDa}$ protein degradation by proteases during purification procedures [23], resulting in a more abundant $55-56 \mathrm{kDa}$ form present on the gel. It is also interesting to notice that the analysis of peptides present in the PMF spectra of MEV purified by HIC did not indicate truncation of protein with apparent MM of $55 \mathrm{kDa}$ (Additional file 1: Figure S4), however such result needs to be further corroborated.

Mature protein $\mathrm{F}$ consists of disulphide linked $\mathrm{F}_{1}$ $\left(\mathrm{MM}_{\mathrm{aa}} 47 \mathrm{kDa}\right)$ and $\mathrm{F}_{2}\left(\mathrm{MM}_{\mathrm{aa}} 13 \mathrm{kDa}\right)$ fragments generated by $F_{0}$ cleavage [2]. The uniqueness of MEV $F$ in comparison to $\mathrm{F}$ protein of other paramyxoviruses is that all glycosylation sites appear to be on the $\mathrm{F}_{2}$ fragment [24-26]. It was proposed that $F_{2}$ is usually not detected by Coomassie staining because of its diffuse nature due 


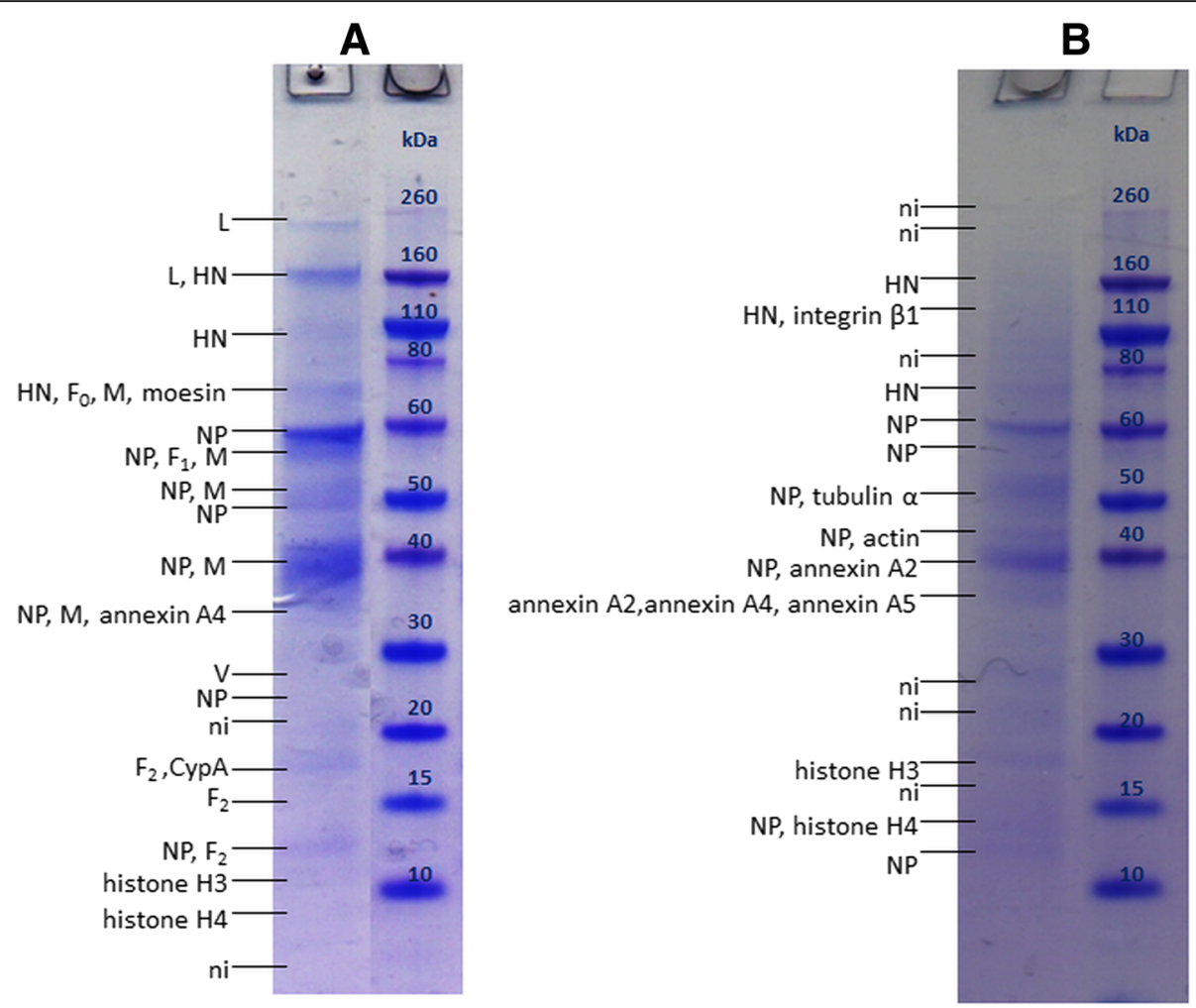

Fig. 5 SDS-PAGE of MUV sample purified by IAC with protein annotations after MALDI-TOF/TOF MS analysis. a and $\mathbf{b}$ represent two separately prepared samples for which the data are listed in Table 1. CypA - cyclophilin A, ni - not identified

to its carbohydrate content [26]. F was found in multiple bands in UC purified $\mathrm{mEV}$, at MMs equal and higher than $\mathrm{MM}_{\mathrm{aa}}$. Bands containing $\mathrm{F}$ which were found around $40 \mathrm{kDa}$ probably contain the non-glycosylated $\mathrm{F}_{1}$ fragment. Since $\mathrm{MM}_{\mathrm{aa}}$ of non-glycosylated precursor $\mathrm{F}_{0}$ would be around $59 \mathrm{kDa}$, bands found around to $59 \mathrm{kDa}$ may contain $\mathrm{F}_{0}$, as previously reported $[25,29]$, however since no peptides corresponding to $F_{2}$ fragment were detected, this cannot be confirmed. Multiple bands containing $F_{1}$ were found in the $50-55 \mathrm{kDa}$ range, however their origin is unclear for now. It is possible that some of them represent palmitoylated $F_{1}$ [50] or degradation products of $\mathrm{F}_{0}$. Cross-contamination between bands as a cause of this phenomenon was excluded due to

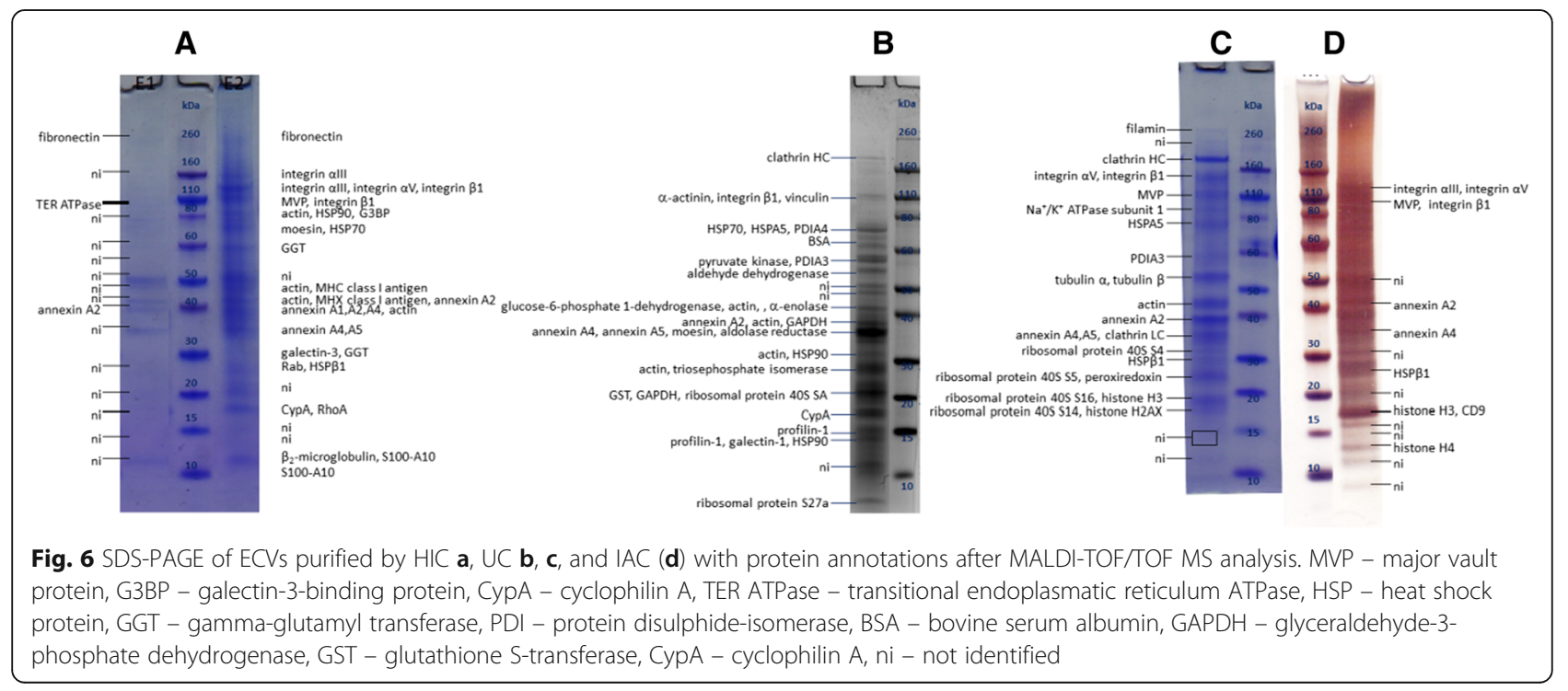


Table 2 Comparative analysis of HCPs present in viruses and ECVs

\begin{tabular}{|c|c|c|c|c|c|c|c|c|c|c|c|c|}
\hline \multirow[t]{3}{*}{ Protein } & \multirow{3}{*}{$\begin{array}{l}\mathrm{MM}^{\mathrm{a}} / \\
\mathrm{kDa}\end{array}$} & \multirow{2}{*}{\multicolumn{3}{|c|}{ UC }} & \multicolumn{6}{|l|}{$\mathrm{HIC}$} & \multirow{2}{*}{\multicolumn{2}{|c|}{ IAC }} \\
\hline & & & & & \multicolumn{3}{|l|}{ E1 } & \multicolumn{3}{|l|}{ E2 } & & \\
\hline & & ECV & MUV & MEV & ECV & MUV & MEV & ECV & MUV & MEV & ECV & MUV \\
\hline heparan sulphate proteoglycan & 469 & & & & & & & & & + & & \\
\hline filamin & 280 & + & & + & & & & & & & & \\
\hline fibronectin & 262 & + & + & + & + & + & + & + & + & + & & \\
\hline clathrin heavy chain $(\mathrm{HC})$ & 192 & + & & + & & & & & & & & \\
\hline vinculin & 124 & + & & & & & & & & & & \\
\hline integrin a III & 117 & & $2 \mathrm{D}$ & & & & & + & & & + & \\
\hline integrin a V & 116 & + & + & & & & & + & & & + & \\
\hline $\mathrm{Na}^{+} / \mathrm{K}^{+}$ATPase subunit 1 & 113 & + & & & & & & & & & & \\
\hline a-actinin & 103 & + & & & + & & & & & & & \\
\hline major vault protein (MVP) & 99 & + & + & & & + & & + & + & & + & \\
\hline transitional endoplasmatic reticulum ATPase (TER ATPase) & 89 & & + & & + & & & & & & & \\
\hline integrin $\beta 1$ & 88 & + & + & + & & & & + & + & + & + & + \\
\hline heat shock protein 90 (HSP90) & 83 & + & & & + & & & + & & & & \\
\hline protein disulphide-isomerase A4 (PDIA4) & 73 & + & & & & & & & & & & \\
\hline heat shock protein A5 (HSPA5) & 72 & + & + & & & & & & & & & \\
\hline heat shock protein 70 (HSP70) & 71 & + & + & + & & & & + & + & & & \\
\hline moesin & 68 & + & + & $2 \mathrm{D}$ & & & & + & + & + & & + \\
\hline BSA (precursor) & 66 & + & & & & & & & & & & \\
\hline galectin-3-binding protein (G3BP) & 65 & & & & & & & + & + & + & & \\
\hline pyruvate kinase & 62 & + & & & & & & & & & & \\
\hline gamma-glutamyltransferase (GGT) & 61 & & & & & & & + & & & & \\
\hline glucose-6-phosphate 1-dehydrogenase & 59 & + & & & & & & & & & & \\
\hline protein disulphide-isomerase A3 (PDIA3) & 57 & + & $2 \mathrm{D}$ & & & & & & & & & \\
\hline aldehyde dehydrogenase & 55 & + & & & & & & & & & & \\
\hline tubulin $\beta$ & 50 & + & + & & & & & & & & & \\
\hline tubulin a & 50 & + & + & $2 \mathrm{D}$ & & & & & & & & + \\
\hline a-enolase & 47 & + & $2 \mathrm{D}$ & + & & & & & & & & \\
\hline actin & 42 & + & + & + & & & + & + & + & + & & + \\
\hline MHC class I antigen & 41 & & & & & & & + & & & & \\
\hline annexins $\mathrm{A} 1, \mathrm{~A} 2, \mathrm{~A} 4, \mathrm{~A} 5$ & 39 & + & + & + & + & + & + & + & + & + & + & + \\
\hline aldolase reductase & 36 & + & $2 \mathrm{D}$ & & & & & & & & & \\
\hline glyceraldehyde 3-phosphate dehydrogenase (GAPDH) & 36 & + & & & & & & & & & & \\
\hline ribosomal protein $40 \mathrm{~S}$ SA & 33 & + & & & & & & & & & & \\
\hline triosephosphate isomerase & 31 & + & $2 \mathrm{D}$ & $2 \mathrm{D}$ & & & & & & & & \\
\hline ribosomal protein $\mathrm{L7a}$ & 30 & & + & & & & & & & & & \\
\hline ribosomal protein $40 S \$ 4$ & 30 & + & & & & & & & & & & \\
\hline clathrin light chain (LC) & 27 & + & & & & & & & & & & \\
\hline chloride intracellular channel protein & 27 & & + & & & & & & & & & \\
\hline galectin-3 & 26 & & $2 \mathrm{D}$ & & & & & + & & & & \\
\hline CD9, CD81 & 25 & & & & & & & & & + & & \\
\hline ras-related protein Rab 5 & 24 & & & & & & & + & & & & \\
\hline glutathione S-transferase (GST) & 23 & + & $2 \mathrm{D}$ & & & & & & & & & \\
\hline
\end{tabular}


Table 2 Comparative analysis of HCPs present in viruses and ECVs (Continued)

\begin{tabular}{|c|c|c|c|c|c|c|c|c|c|c|c|c|}
\hline \multirow[t]{3}{*}{ Protein } & \multirow{3}{*}{$\begin{array}{l}\mathrm{MM}^{\mathrm{a}} / \\
\mathrm{kDa}\end{array}$} & \multirow{2}{*}{\multicolumn{3}{|c|}{ UC }} & \multicolumn{6}{|l|}{$\mathrm{HIC}$} & \multirow{2}{*}{\multicolumn{2}{|c|}{ IAC }} \\
\hline & & & & & \multicolumn{3}{|l|}{$\overline{\text { E1 }}$} & \multicolumn{3}{|l|}{ E2 } & & \\
\hline & & $\overline{E C V}$ & MUV & MEV & ECV & MUV & MEV & ECV & MUV & MEV & ECV & MUV \\
\hline ribosomal protein $40 \mathrm{~S}$ S5 & 23 & + & & & & & & & & & & \\
\hline heat shock protein $\beta 1$ (HSP $\beta 1$ ) & 23 & + & + & $2 \mathrm{D}$ & & & & + & & & + & \\
\hline RhoA & 22 & & & & & & & + & & & & \\
\hline peroxiredoxin & 22 & + & $2 \mathrm{D}$ & $2 \mathrm{D}$ & & & & & & & & \\
\hline cyclophilin A (CypA) & 18 & + & + & + & & & & + & + & + & & + \\
\hline ubiquitin-ribosomal protein S27a & 18 & + & & $2 \mathrm{D}$ & & & & & & & & \\
\hline ribosomal protein $40 S \mathrm{S16}$ & 16 & + & + & & & & & & & & & \\
\hline ribosomal protein $40 \mathrm{~S} S 14$ & 16 & + & & & & & & & & & & \\
\hline galectin-1 & 15 & + & & $2 \mathrm{D}$ & & & & & & & & \\
\hline profilin-1 & 15 & + & & & & & & & & & & \\
\hline histone $\mathrm{H} 3$ & 15 & + & + & + & & & & & & & + & + \\
\hline histone $\mathrm{H} 2 \mathrm{AX}$ & 15 & + & + & + & & & & & & & & \\
\hline$\beta_{2}$-microglobulin & 14 & + & & & & & & & & & & \\
\hline ribosomal protein 60S L30 & 13 & & + & & & & & & & & & \\
\hline S100-A11 & 12 & & $2 \mathrm{D}$ & & & & & + & & & & \\
\hline histone $\mathrm{H} 4$ & 11 & & + & + & & & & & & & + & + \\
\hline S100-A10 & 11 & & & & & & & + & & & & \\
\hline
\end{tabular}

${ }^{a}$ molecular mass of a monomer is given

2D - indicates that the protein was detected in 2D gel electrophoresis of UC purified MEV (Table 1, sample C and Fig. 1(C)) or MUV (Table 1, sample (C) and Fig. 2(C)), but not when these samples were resolved only by SDS-PAGE (for further information see Additional file 1: Figure S6 \& Table S1)

meticulous work in this and all other samples in which this occurs.

Protein $\mathrm{M}$ also appeared at several bands at MM equal and higher than its $\mathrm{MM}_{\mathrm{aa}}(40-60 \mathrm{kDa})$. The doublet of bands around 37-39 kDa was previously reported for MEV $M$, and some smearing of $M$ was reported even under reducing conditions [51]. Although biologically active form of $M$ seems to be a dimer [51, 52], this does not explain the occurrence of these bands. The origin of $M$ in multiple bands remains to be elucidated.

Protein $\mathrm{P}$ was detected at 2 to 3 bands in different MEV samples. The bands detected at approximately $53 \mathrm{kDa}$ correspond well to $\mathrm{MM}_{\mathrm{aa}}$ of $\mathrm{P}(54 \mathrm{kDa})$, thus likely corresponding to the protein without any posttranslational modifications. In the virions $\mathrm{P}$ is heavily phosphorylated [53], thus carrying large negative charge, therefore its migration in the gel should be retarded. This implies that the bands detected at approximately $60 \mathrm{kDa}$ probably present posttranslationally modified P. $\mathrm{P}$ which was detected in bands at higher MMs $(110 \mathrm{kDa}$ and more) likely represents oligomers of $\mathrm{P}$, since $\mathrm{P}$ is known to be a self-associated oligomer [54]. In previous reports $\mathrm{P}$ was also readily found in bands ranging from 65 to $70 \mathrm{kDa}[23,25,29]$.

Viral protein $\mathrm{L}\left(\mathrm{MM}_{\mathrm{aa}} 248 \mathrm{kDa}\right)$ was found at its corresponding MM in UC purified MEV, but in HIC purified
MEV it remained undetected. This was probably due to its low abundance combined with its co-migration with much more abundant fibronectin, which might result in peptide desorption/ionization suppression.

\section{MUV}

Results obtained for MUV in this study are similar to those previously published [32]. Although protein $\mathrm{V}$ is still often considered to be a non-structural protein and is not necessary for MUV replication [12, 16], it was shown to be present in all the samples analysed in this study, which is in line with previously published studies $[32,55]$.

Protein $\mathrm{HN}$ was detected in 2 to 4 bands at MMs ranging from 70 to $200 \mathrm{kDa}$, which is higher than its $\mathrm{MM}_{\mathrm{aa}}$ (64 kDa). This indicates its presence as glycosylated monomer and dimer, as previously reported [32, 56]. The novelty is that in the sample on Fig. 2(c) HN was present in 4 bands, indicating that different glycoforms are likely present.

Protein NP was detected in up to 4 bands, at MM equal or lower than its $\mathrm{MM}_{\mathrm{aa}}$, and the comparison of detected peptides in the PMF spectra of UC and HIC purified samples (Additional file 1: Figures S3 and S5, respectively) again indicates $\mathrm{C}$-truncation of proteins 
present in the bands at MMs lower than $61 \mathrm{kDa}$, as described in our previous study [32]. Interestingly, in the present study, in HIC purified MUV full-length NP was not detected. When this is considered in parallel with the finding that lower $\mathrm{MM}$ forms of $\mathrm{N}$ are also more abundant in all MEV samples, it indicates some processes occur, either during virus production in the cells, or during virus purification, which result in more abundant truncated forms.

In this study, for the first time in UC and IAC purified MUV, fragment $F_{2}$ of protein $F$ was found at MM higher than it $M_{\mathrm{aa}}$, indicating it is present in its glycosylated form. In HIC purified MUV, the band found around $57 \mathrm{kDa}$ contained only peptides of $\mathrm{F}_{1}$ fragment, indicating it contains glycosylated $\mathrm{F}_{1}$, since its $\mathrm{MM}_{\mathrm{aa}}$ is $47 \mathrm{kDa}$. The band around $65 \mathrm{kDa}$ contains peptides from both $\mathrm{F}_{1}$ and $F_{2}$ fragments, indicating the presence of glycosylated $\mathrm{F}_{0}$ precursor, since its $\mathrm{MM}_{\mathrm{aa}}$ is $59 \mathrm{kDa}[21,22,30]$.

In this study, in UC purified MUV samples protein $\mathrm{P}$ was not detected, which is unexpected since it was previously detected in MUV purified by UC [32]. Reports exist showing it is susceptible to protease degradation, which might explain its absence from the gel $[23,54]$.

In this study, the comparison of two HIC elution fractions, E1 and E2, reveals different protein patterns for both MEV and MUV, which are consistent with other findings such as total and infective particle number as seen in Table 1. It becomes clear that more viral proteins are present in E2 fraction which also contains more infective particles, as previously reported [43]. All these findings indicate that particles in fractions E1 and E2 differ significantly, possibly presenting different virus subpopulations [57].

\section{Host cell proteins in virus and ECV preparations purified by different purification methods}

The presence of ECVs in virus preparations, which was often neglected, complicates determination of HCPs present only in virions and not in ECVs. Here, for the first time, this problem was addressed by comparative analysis of the results obtained for viruses and ECVs purified by different purification methods. Chromatographic techniques such as HIC and IAC result in virus preparations of higher purity in comparison to UC. This is easily observed through total-to-infective particle ratio in such samples, as well as in HCP content when compared to starting material $[5,47,48]$. Comparison of results obtained by different purification methods helps in estimating purification efficiency of these methods, as well as estimation if a method results in enrichment of certain particles (e.g. infective or non-infective virus particles, ECVs) or HCPs in comparison to other available methods.

ECVs were long ago shown to be a major contaminant of virus preparations, as well as a source of HCPs present in such virus preparations [38, 39]. ECVs are similar to MUV and MEV in size - ECVs produced by non-infected Vero cells used in our experiments have a mean diameter of $199 \pm 3.8 \mathrm{~nm}(n=39$, updated data from [43]), whereas MUV and MEV have mean diameters of $215 \pm 1.9 \mathrm{~nm}$ and $206 \pm 2.5 \mathrm{~nm}$, respectively ( $n=67$ and $n=68$, respectively, updated data from [5]). Similarity of ECVs to enveloped viruses in size, density and composition makes the preparation of ECV-free virus samples virtually impossible by methods currently available, and in case that production of ECVs is not greatly affected during infection (increased or diminished), up to one third of particles in virus suspensions may be ECVs [43].

Here the evaluation of which HCPs might be part of the virions was carried out for the first time by comparing HCPs detected in virus preparations purified by different purification methods, and with HCPs present in ECVs produced by non-infected Vero cells. The hypothesis beneath this comparative analysis is that, if an $\mathrm{HCP}$ is virion-associated, it will be present in all virus samples, regardless of the purification method used. Otherwise, if the $\mathrm{HCP}$ is present in virus preparation obtained only by some purification methods, it is more likely to be a contamination arising from the ECVs present in the virus preparation. To confirm the incorporation of such HCPs into ECVs, a comparison to the proteome of purified ECVs from non-infected Vero cells was carried out under the hypothesis that the composition of ECVs produced by infected and non-infected Vero cells is the same. Although the protein composition of ECVs might change during infection, since ECVs produced by infected cells cannot be distinguished and separated from viral particles in the supernatant of the infected cell culture, the results presented here still give a valuable insight into which HCPs are more likely to be present in viral preparations due to their association with viral particles, and which due to inevitable presence of ECVs in virus preparations.

All of the proteins detected in ECV samples are considered to be exosome markers [58], except BSA which is likely a contaminant originating from FCS used in cell culture media during production of ECVs [59].

Fibronectin was found in MUV and MEV, as well as ECVs, and in fraction E1 of HIC purified samples it is present in very high concentrations. Since it is unlikely that any particles (virions or ECVs) would contain such high concentrations of fibronectin as seen in E1, fibronectin is probably co-purified from culture supernatant by HIC under used conditions, with most protein eluting in E1 fraction. Since samples were concentrated by UC prior to SDS-PAGE, free proteins present in the eluates should be removed as the forces during $\mathrm{UC}$ are not strong enough to pellet free proteins. However, high salt concentration used in $\mathrm{HIC}$ (in this case $\left.1 \mathrm{M}\left(\mathrm{NH}_{4}\right)_{2} \mathrm{SO}_{4}\right)$ can cause fibronectin 
aggregation and even precipitation $[60,61]$. Therefore, it is presumed that fibronectin has possibly formed large aggregates during HIC purification, which pelleted at $141,000 \times g$ used for UC. Fibronectin has previously been reported in MUV samples purified by UC [32], and it was also detected here in UC purified samples. Its presence in most samples might imply its involvement in particle formation; however, its absence from IAC purified MUV indicates that it might just be a contamination.

Actin, annexins (A1, A2, A4, A5) and cyclophilin A (CypA) are readily found in all samples which, combined with previous reports, strongly supports hypothesis that these proteins are in fact part of the virions. Presence of actin in MEV and MUV was previously reported [20, 21, 26, 31, 62]. It was shown that viruses use cytoskeletal proteins such as actin for transport of viral components inside the cell, as well as in virus budding and maturation [34, 62]. Actin was found to interact with ribonucleocapsid in MEV, and it also seems to interact with ribonucleocapsid, $M$ and glycoproteins of some other paramyxoviruses [62-65]. It is likely responsible for maintaining the architecture of virions [42] and ECVs, hence its presence inside the particles is expected. In virions, it might have an additional function, e.g. it was found to be involved in genome transcription in several paramyxoviruses $[64,66]$.

Annexins are present in the cytoplasm but can also be bound to the plasma membrane surface. Annexin A2 binds cellular actin and is involved in its organization in the proximity of plasma membrane [34]. It is hypothesized that annexins as a part of viral particles aid the attachment of viruses on the host cells and fusion of virus and plasma membrane so it would be logical that they play the same role in the fusion of ECVs and cells. Although contradictory findings about the role of annexin A2 in virus infection have been published [67-70], it is possible that it might be important for infective virus formation in some cell lines [70].

Cyclophilin A (CypA) is highly abundant cytosolic protein acting as peptidyl-prolyl isomerase and is therefore often classified as a chaperone. Its presence in the particles might simply arise from its high abundance in the cytoplasm, but it could be incorporated into virions through interaction with viral proteins due to its chaperone function. It has been hypothesized that in some viruses it helps the formation of viral particles or uncoating after the infection, and it was also shown to be necessary for infective HIV-1 production $[33,35]$.

Integrin $\beta 1$ and moesin were consistently found in both virus and ECV samples, regardless of the purification method. Their presence in IAC purified MUV supports the hypothesis that they are in fact included in virus particles. Integrin $\beta 1$ was previously reported in vesicular stomatitis virus [71], whereas moesin was found in HIV [72]. Since integrins act as membrane receptors, and are involved in connecting extracellular matrix to cytoskeleton, and moesin is involved in the interaction of actin cytoskeleton with the plasma membrane, they are likely present at the virus budding sites and hence included into virions. Whether they have a specific role in the virus lifecycle itself remains unclear, although they seem to be important for the virus uptake to the cells $[73,74]$.

Virtually all of the detected HCPs have been previously reported as proteins present inside of purified virus particles [33-37, 42, 59, 62, 63, 65, 66, 71, 75-77]. However, one should be aware that co-purified ECVs contribute to detected HCPs [38, 39, 41]. Also, protein composition of ECVs might change during virus infection hence yielding ECVs of different composition, and this further underlines that co-purification of ECVs with viruses should not be neglected.

\section{Conclusions}

Our research on MUV and MEV proteome resulted in detection of all viral proteins except V in MEV and $\mathrm{SH}$ and I in MUV, which might indicate that they are not incorporated in virions, especially since previous studies showed they were not necessary for virus replication. Different purification methods resulted in samples of different purity, but differences are also obvious between samples purified by the same methods. This is in line with already observed day-to-day variations [43]. Large-scale preparations would be needed to evaluate possible day-to-day proteome differences. Interestingly, many viral proteins occur in several bands, where only NP and N occur at theoretical molecular mass and lower, whereas all other multiple-band proteins occur at theoretical molecular mass and higher. All HCPs detected in the viruses are present in ECVs as well, indicating that they have some function in vesicle exit from the cell, or that they might only be present in ECVs. Presence of actin, annexins, CypA, integrin $\beta 1$ and moesin in all virus samples indicates they are likely virion-associated, i.e. part of the virions, whereas further investigation is needed to confirm the incorporation of other HCPs into the virions.

\section{Additional file}

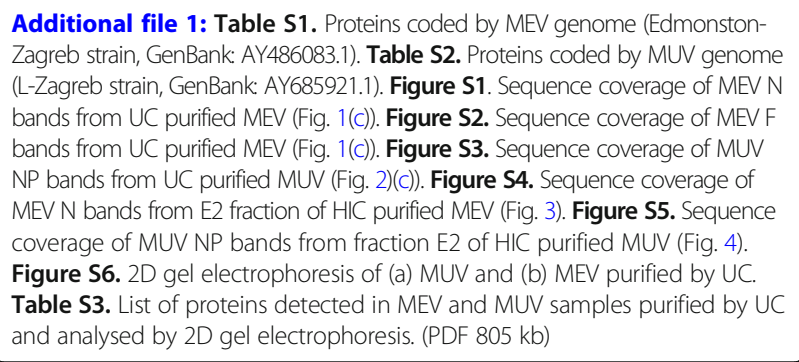

Abbreviations

CypA: Cyclophilin A; ECV: Extracellular vesicle; F: Fusion protein

G3BP: Galectin-3 binding protein; H: Hemagglutinin; HCP: Host cell protein; 
HIC: Hydrophobic interaction chromatography; HN: Hemagglutininneuraminidase; IAC: Immunoaffinity chromatography; L: Large protein; M: Matrix protein; MALDI: Matrix-assisted laser desorption/ionization; MEV: Measles virus; MM: Molecular mass; MS: Mass spectrometry; MUV: Mumps virus; N/NP: Nucleoprotein; NTA: Nanoparticle tracking analysis; P: Phosphoprotein; SH: Small hydrophobic protein; UC: Ultracentrifugation

\section{Acknowledgments}

The authors thank Mrs. Renata Jug for excellent technical assistance. Any opinions, findings and conclusions or recommendations expressed in this material are those of the authors and do not necessarily reflect the views of Croatian Science Foundation.

\section{Funding}

This work was funded by Croatian Science Foundation (grant No. 8193 to MB), bilateral Croatian-Austrian project (grant HR 13/2016 to MMD), and the grant "Strengthening the capacity of CerVirVac for research in virus immunology and vaccinology", KK.01.1.1.01.0006, awarded to the Scientific Centre of Excellence for Virus Immunology and Vaccines and co-financed by the European Regional Development Fund. The funding sources were not involved in study design, data collection, analysis or interpretation, as well as manuscript writing and decision to submit the manuscript.

\section{Availability of data and materials}

All data generated or analysed during this study are included in this published article and its supplementary information files.

\section{Authors' contributions}

All authors designed the study. DF, MB and DS prepared the virus samples. DS performed MS experiments. DS, MB and BH analysed the results. DS, MB and BH wrote the manuscript draft. All authors read and approved the final manuscript.

\section{Ethics approval and consent to participate}

Not applicable.

\section{Consent for publication}

Not applicable.

\section{Competing interests}

The authors declare that they have no competing interest.

\section{Publisher's Note}

Springer Nature remains neutral with regard to jurisdictional claims in published maps and institutional affiliations.

\section{Author details}

'Centre for Research and Knowledge Transfer in Biotechnology, University of Zagreb, Rockefellerova 10, HR-10 000 Zagreb, Croatia. ${ }^{2}$ Centre of Excellence for Viral Immunology and Vaccines, CERVirVac, Zagreb, Croatia. ${ }^{3}$ Institute of Chemical Technologies and Analytics, TU Wien, Getreidemarkt 9, AT-1060 Vienna, Austria.

\section{Received: 22 July 2018 Accepted: 2 October 2018}

\section{Published online: 16 October 2018}

\section{References}

1. Duc-Nguyen H, Rosenblum EN. Immuno-electron microscopy of the morphogenesis of mumps virus. J Virol. 1967;1:415-29.

2. Griffin DE. Measles Virus. In: Knipe DM, Howley PM, editors. Fields Virol. 6th ed. Philadelphia: Lippincott Williams \& Wilkins; 2013. p. 1042-69.

3. Rubin SA, Sauder CJ, Carbone KM. Mumps Virus. In: Knipe DM, Howley PM, editors. Fields Virol. 6th ed. Philadelphia: Lippincott Williams \& Wilkins; 2013. p. 1024-41.

4. Weiss K, Salzig D, Röder Y, Gerstenberger J, Mühlebach MD, Cichutek K, et al. Influence of process conditions on measles virus stability. Am J Biochem Biotechnol. 2013;9:243-54.

5. Sviben D, Forčić D, Kurtović T, Halassy B, Brgles M. Stability, biophysical properties and effect of ultracentrifugation and diafiltration on measles virus and mumps virus. Arch Virol. 2016;161:1455-67.

6. Kingston RL, Baase WA, Gay LS. Characterization of nucleocapsid binding by the measles virus and mumps virus phosphoproteins characterization of nucleocapsid binding by the measles virus and mumps virus phosphoproteins. J Virol. 2004;78:8630-40.

7. Li M, Schmitt PT, Li Z, McCrory TS, He B, Schmitt AP. Mumps virus matrix, fusion, and nucleocapsid proteins cooperate for efficient production of virus-like particles. J Virol. 2009;83:7261-72.

8. Liljeroos L, Huiskonen JT, Ora A, Susi P, Butcher SJ. Electron cryotomography of measles virus reveals how matrix protein coats the ribonucleocapsid within intact virions. Proc Natl Acad Sci U S A. 2011;108:18085-90.

9. Ruigrok RWWH, Crépin T, Kolakofsky D. Nucleoproteins and nucleocapsids of negative-strand RNA viruses. Curr Opin Microbiol. 2011;14:504-10.

10. El Najjar F, Schmitt AP, Dutch RE. Paramyxovirus glycoprotein incorporation, assembly and budding: a three way dance for infectious particle production. Viruses. 2014:6:3019-54.

11. Bellini WJ, Englund G, Rozenblatt S, Arnheiter H, Richardson CD. Measles virus P gene codes for two proteins. J Virol. 1985:53:908-19.

12. Paterson RG, Lamb A. RNA editing by G-nucleotide insertion in mumps virus P-gene mRNA transcripts. J Virol. 1990;64:4137-45.

13. Radecke F, Billeter MA. The nonstructural $C$ protein is not essential for multiplication of Edmonston B strain measles virus in cultured cells. Virology. 1996;217:418-21.

14. Escoffier C, Manie S, Vincent S, Muller CP, Billeter M, Gerlier D. Nonstructural protein $C$ is required for efficient measles virus replication in human peripheral blood cells. J Virol. 1999;73:1695-8.

15. Patterson JB, Thomas D, Lewicki H, Billeter MA, Oldstone MBA. V and C proteins of measles virus function as virulence factors in vivo. Virology. 2000;267:80-9.

16. Xu P, Luthra P, Li Z, Fuentes $S, D^{\prime}$ Andrea JA, Wu J, et al. The $V$ protein of mumps virus plays a critical role in pathogenesis. J Virol. 2012;86:1768-76.

17. Wilson RL, Fuentes SM, Wang P, Taddeo EC, Klatt A, Henderson AJ, et al. Function of small hydrophobic proteins of paramyxovirus. J Virol. 2006;80: 1700-9.

18. Takeuchi K, Tanabayashi K, Hishiyama M, Yamada A. The mumps virus SH protein is a membrane protein and not essential for virus growth. Virology. 1996;225:156-62.

19. Hall WW, Martin SJ. Purification and characterization of measles virus. J Gen Virol. 1973;19:175-88.

20. Jensik SC, Silver S. Polypeptides of mumps virus. J Virol. 1976;17:363-73.

21. Naruse H, Nagai $Y$, Yoshida T, Hamaguchi M, Matsumoto T, Isomura S, et al. The polypeptides of mumps virus and their synthesis in infected chick embryo cells. Virology. 1981;112:119-30.

22. Herrler G, Compans RW. Synthesis of mumps virus polypeptides in infected Vero cells. Virology. 1982;119:430-8.

23. Swoveland PT. Isolation of measles virus polypeptides from infected brain tissue by affinity chromatography. J Virol Methods. 1986;13:333-41.

24. Mountcastle WE, Choppin PW. A comparison of the polypeptides of four measles virus strains. Virology. 1977;78:463-74

25. Graves MC, Silver SM, Choppin PW. Measles virus polypeptide synthesis in infected cells. Virology. 1978;86:254-63.

26. Tyrrell DLJ, Norrby E. Structural polypeptides of measles virus. J Gen Virol. 1978;39:219-29.

27. Hardwick JM, Bussell RH. Glycoproteins of measles virus under reducing and nonreducing conditions. J Virol. 1978;25:687-92.

28. Orvell C. Structural polypeptides of mumps virus. J Gen Virol. 1978:41:527-39.

29. Rima BK, Martin SJ. Effect of undiluted passage on the polypeptides of measles virus. J Gen Virol. 1979:44:135-44.

30. Rima BK, Roberts MW, McAdam WD, Martin SJ. Polypeptide synthesis in mumps virus-infected cells. J Gen Virol. 1980;46:501-5.

31. McCarthy M, Johnson RT. A comparison of the structural polypeptides of five strains of mumps virus. J Gen Virol. 1980;46:15-27.

32. Brgles $M$, Bonta $M$, Šantak M, Jagušić $M$, Forčić $D$, Halassy $B$, et al. Identification of mumps virus protein and lipid composition by mass spectrometry. Virol J. 2016;13:9.

33. Cantin R, Méthot $\mathrm{S}$, Tremblay MJ. Plunder and stowaways: incorporation of cellular proteins by enveloped viruses. J Virol. 2005;79:6577-87.

34. Shaw ML, Stone KL, Colangelo CM, Gulcicek EE, Palese P. Cellular proteins in influenza virus particles. PLoS Pathog. 2008;4:e1000085.

35. Franke EK, Yuan HEH, Luban J. Specific incorporation of cyclophilin a into HIV-1 virions. Nature 1994:372:359-62.

36. Michael K, Klupp BG, Mettenleiter TC, Karger A. Composition of pseudorabies virus particles lacking tegument protein US3, UL47, or UL49 or envelope glycoprotein E. J Virol. 2006;80:1332-9. 
37. Chertova E, Chertov O, Coren LV, Roser JD, Trubey CM, Bess JW, et al. Proteomic and biochemical analysis of purified human immunodeficiency virus type 1 produced from infected monocyte-derived macrophages. J Virol. 2006;80:9039-52.

38. Bess JW, Gorelick RJ, Bosche WJ, Henderson LE, Arthur LO. Microvesicles are a source of contaminating cellular proteins found in purified HIV-1 preparations. Virology. 1997;230:134-44.

39. Gluschankof P, Mondor I, Gelderblom HR, Sattentau QJ. Cell membrane vesicles are a major contaminant of gradient-enriched human immunodeficiency virus type-1 preparations. Virology. 1997;230:125-33.

40. El Andaloussi S, Mäger I, Breakefield XO, Wood MJA. Extracellular vesicles: biology and emerging therapeutic opportunities. Nat Rev Drug Discov. 2013:12:347-57.

41. Nolte-'t Hoen E, Cremer T, Gallo RC, Margolis LB. Extracellular vesicles and viruses: are they close relatives? Proc Natl Acad Sci U S A. 2016;113:9155-61.

42. Radhakrishnan A, Yeo D, Brown G, Myaing MZ, lyer LR, Fleck R, et al. Protein analysis of purified respiratory syncytial virus particles reveals an important role for heat shock protein 90 in virus particle assembly. Mol Cell Proteomics. 2010;9:1829-48.

43. Sviben D, Forčić D, Ivancic-Jelecki J, Halassy B, Brgles M. Recovery of infective virus particles in ion-exchange and hydrophobic interaction monolith chromatography is influenced by particle change and total-toinfective particle ratio. J Chromatogr B Anal Technol Biomed Life Sci. 2017 1054:10-9.

44. Brgles M, Sviben D, Forčić D, Halassy B. Nonspecific native elution of proteins and mumps virus in immunoaffiity chromatography. J Chromatogr A. $2016 ; 1447: 107-14$

45. World Health Organization. Live measles virus vaccine. In: manual of laboratory methods, document WHO/NSQ/9704. Geneva: World Health Organization; 1997. p. 79-82.

46. Forcic D, Košutić-Gulija T, Šantak M, Jug R, Ivancic-Jelecki J, Markusic M, et al. Comparisons of mumps virus potency estimates obtained by $50 \%$ cell culture infective dose assay and plaque assay. Vaccine. 2010;28:1887-92.

47. Shevchenko A, Wilm M, Vorm O, Mann M. Mass spectrometric sequencing of proteins from silver-stained polyacrylamide gels. Anal Chem. 1996;68:850-8.

48. Brgles M, Kurtovic T, Kovacic L, Križaj I, Barut MM, Balija ML, et al. Identification of proteins interacting with ammodytoxins in Vipera ammodytes ammodytes venom by immuno-affinity chromatography. Anal Bioanal Chem. 2014:406:293-304.

49. Greco TM, Diner BA, Cristea IM. The impact of mass spectrometry-based proteomics on fundamental discoveries in virology. Annu Rev Virol. 2014;1:581-604.

50. Caballero M, Carabana J, Ortego J, Fernandez-Munoz R, Celma ML. Measles virus fusion protein is palmitoylated on transmembrane-intracytoplasmic cysteine residues which participate in cell fusion. J Virol. 1998;72:8198-204.

51. Pohl C, Duprex WP, Krohne G, Rima BK, Schneider-Schaulies S. Measles virus $\mathrm{M}$ and $\mathrm{F}$ proteins associate with detergent-resistant membrane fractions and promote formation of virus-like particles. J Gen Virol. 2007;88:1243-50.

52. Förster A, Maertens GN, Farrell PJ, Bajorek M. Dimerization of matrix protein is required for budding of respiratory syncytial virus. J Virol. 2015;89:4624-35.

53. Fuentes S, Sun D, Schmitt A, He B. Phosphorylation of paramyxovirus phosphoprotein and its role in viral gene expression. Future Microbiol. 2010;5:9-13

54. Cox R, Green TJ, Purushotham S, Deivanayagam C, Bedwell GJ, Prevelige PE, et al. Structural and functional characterization of the mumps virus phosphoprotein. J Virol. 2013;87:7558-68.

55. Takeuchi K, Tanabayashi K, Hishiyama M, Yamada Y, Yamada A, Sugiura A. Detection and characterization of mumps virus V protein. Virology. 1990; 178:247-53.

56. Waxham MN, Merz DC, Wolinsky JS. Intracellular maturation of mumps virus hemagglutinin-neuraminidase glycoprotein: conformational changes detected with monoclonal antibodies. J Virol. 1986;59:392-400.

57. Šantak M, Markušić M, Balija ML, Kopač SK, Jug R, Örvell C, et al. Accumulation of defective interfering viral particles in only a few passages in Vero cells attenuates mumps virus neurovirulence. Microbes Infect. 2015; 17:228-36.

58. Mathivanan S, Simpson RJ. ExoCarta: a compendium of exosomal proteins and RNA. Proteomics. 2009;9:4997-5000.

59. Kattenhorn LM, Mills R, Wagner M, Lomsadze A, Makeev V, Borodovsky M, et al. Identification of proteins associated with murine cytomegalovirus virions. J Virol. 2004;78:11187-97.
60. Heuvel MJ, Van Den JBJ, Jacobs RM. Isolation of a bovine plasma fibronectin-containing complex which inhibits the expression of bovine leukemia virus p24. J Virol. 2005;79:8164-70.

61. Bollineni RC, Guldvik IJ, Grönberg H, Wiklund F, Mills IG, Thiede B. A differential protein solubility approach for the depletion of highly abundant proteins in plasma using ammonium sulfate. Analyst. 2015;140:8109-17.

62. Moyer SA, Baker SC, Horikami SM. Host cell proteins required for measles virus reproduction. J Gen Virol. 1990;71:775-83.

63. Giuffre RM, Tovell DR, Kay CM, Tyrrell DL. Evidence for an interaction between the membrane protein of a paramyxovirus and actin. J Virol. 1982; 42:963-8.

64. Cudmore S, Reckmann I, Michael W. Viral manipulations of the actin cytoskeleton. Trends Microbiol. 1997:5:142-8.

65. Ulloa L, Serra R, Asenjo A, Villanueva N. Interactions between cellular actin and human respiratory syncytial virus (HRSV). Virus Res. 1998:53:13-25.

66. Brown G, Rixon HWM, Steel J, McDonald TP, Pitt AR, Graham S, et al. Evidence for an association between heat shock protein 70 and the respiratory syncytial virus polymerase complex within lipid-raft membranes during virus infection. Virology. 2005;338:69-80.

67. Pietropaolo RL, Compton T. Direct interaction between human cytomegalovirus glycoprotein B and cellular annexin II. J Virol. 1997;71: 9803-7.

68. Pietropaolo R, Compton T. Interference with annexin II has no effect on entry of human cytomegalovirus into fibroblast cells. J Gen Virol. 1999;80: 1807-16.

69. Ryzhova EV, Harrist AV, Harvey T, Gonza F. Annexin 2: a novel human immunodeficiency virus type 1 gag binding protein involved in replication in monocyte-derived macrophages. J Virol. 2006;80:2694-704.

70. Rai T, Mosoian A, Resh MD. Annexin 2 is not required for human immunodeficiency virus type 1 particle production but plays a cell typedependent role in regulating infectivity. J Virol. 2010;84:9783-92.

71. Moerdyk-Schauwecker M, Hwang S-I, Grdzelishvili VZ. Analysis of virion associated host proteins in vesicular stomatitis virus using a proteomics approach. Virol J. 2009;6:166.

72. Ott DE, Coren LV, Johnson DG, Kane BP, Sowder RC, Kim YD, et al. Actinbinding cellular proteins inside human immunodeficiency virus type 1. Virology. 2000;266:42-51.

73. Schneider-Schaulies J, Dunster LM, Schwartz-Albiez R, Krohne G, Ter Meulen $\checkmark$. Physical association of moesin and CD46 as a receptor complex for measles virus. J Virol. 1995;69:2248-56.

74. Cseke G, Maginnis MS, Cox RG, Tollefson SJ, Podsiad AB, Wright DW, et al. Integrin av $\beta 1$ promotes infection by human metapneumovirus. Proc Natl Acad Sci U S A. 2009;106:1566-71.

75. Johannsen E, Luftig M, Chase MR, Weicksel S, Cahir-McFarland E, Illanes D, et al. Proteins of purified Epstein - Barr virus. Proc Natl Acad Sci U S A. 2004; 101:16286-91.

76. Tremblay MJ, Fortin J-F, Cantin R. The acquisition of host-encoded proteins by nascent HIV-1. Immunol Today. 1998;19:346-51.

77. Chung C, Chen C, Ho M, Huang C. Vaccinia virus proteome: Identification of proteins in vaccinia virus intracellular mature virion particles. J Virol. 2006:80: 2127-40.

\section{Ready to submit your research? Choose BMC and benefit from:}

- fast, convenient online submission

- thorough peer review by experienced researchers in your field

- rapid publication on acceptance

- support for research data, including large and complex data types

- gold Open Access which fosters wider collaboration and increased citations

- maximum visibility for your research: over $100 \mathrm{M}$ website views per year

At $\mathrm{BMC}$, research is always in progress.

Learn more biomedcentral.com/submissions 